\title{
Energy absorption as a measure of intestinal failure in the short bowel syndrome
}

\author{
C A RODRIGUES, J E LENNARD-JONES, D G THOMPSON, \\ AND M J G FARTHING
}

From St Mark's Hospital, London

SUMMARY Energy absorption from a liquid test meal, intestinal transit rate and water and sodium output over a six hour period were measured in five patients with an ileostomy and 12 patients with the short bowel syndrome, five of whom were on longterm parenteral nutrition. The proportion of total energy absorbed was greatest in the ileostomists (median 87\%, range 82-92\%), less in short bowel patients not on parenteral nutrition (median $67 \%$, range $59-78 \%, p<0.01$ ) and least in the short bowel group who needed it (median $27 \%$, range $2-63 \%, p<0.01$ ). Transit rate was more rapid in the short bowel patients compared with the ileostomists. A close correlation was observed between percentage energy absorption and the dry weight of the stools/stoma effluent collected during the six hour test period $(r=-0.99, p<0.001)$. This simple non-invasive test quantitates the degree of intestinal failure and may be of practical help in management.

Patients with the short bowel syndrome are prone to malnutrition and salt and water depletion as a result of their reduced capacity to absorb nutrients, water, and electrolytes. ${ }^{1-5}$ Most patients with less than 80 $100 \mathrm{~cm}$ of small bowel will need parenteral nutrition indefinitely. ${ }^{14}$ There are exceptions to this general rule, however, ${ }^{6-9}$ because the severity of intestinal failure is not determined exclusively by the length of remaining bowel. Other factors such as the site of resection, the presence of mucosal disease, and the degree of adaptation that has taken place will also influence the final outcome. Furthermore, measurement of intestinal length at surgery may be subject to error for technical reasons and also because length depends on contraction of longitudinal muscle during a single operative procedure. ${ }^{4}$

A functional measure of absorptive capacity would circumvent these difficulties and could identify those patients likely to need longterm parenteral nutrition. Moreover, if such a test were simple and noninvasive, it could be repeated at intervals, thus providing a clinically useful measure of intestinal

Address for correspondence: Professor J E Lennard-Jones, Medical Research Department, St Mark's Hospital, City Road, London EC1V 2PS.

Accepted for publication 4 August 1988. adaptation. In this study, energy absorption from a widely available polymeric liquid feed (Ensure, Abbott Laboratories) was determined in 17 patients who had undergone varying degrees of intestinal resection, using bomb calorimetry.

\section{Methods}

PROTOCOL

The studies described below were approved by the Ethical Committee of the City and Hackney District Health Authority. Five ileostomists and 12 patients with the short bowel syndrome were studied. All antidiarrhoeal medication was omitted 48 hours before each study. After an overnight fast patients drank a liquid test meal (Ensure $300 \mathrm{ml}$, Table 1), labelled with $5 \mu \mathrm{Ci}[3 \mathrm{H}]$-polyethylene glycol, molecular weight 4000 , ([3H]-PEG), over about 10-15 minutes. The stoma effluent or stools were then collected for the next six hours during which patients were not allowed oral food or fluids. In patients with a stoma, the effluent was collected at timed intervals, initially every 30 minutes, but subsequently at longer intervals as the volume decreased. The single patient without a stoma (no 17) had a jejunorectal anastomosis and collected all the 
Table 1 Test meal

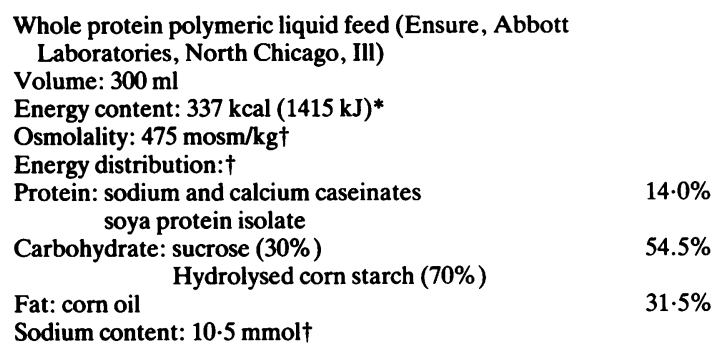

*Energy content of each test meal $(n=17)$ measured by bomb calorimetry was found to be 337 (2) kcal (mean (SE));

†Manufacturer's data.

stools passed during the test period into a single container. In two patients (nos 12 and 17) the study was repeated on another day.

A fasting collection under identical conditions was obtained in eight patients.

\section{PATIENTS}

Three groups of patients were studied:

\section{Group 1. Ileostomists (Table 2)}

These five patients had had no more than $60 \mathrm{~cm}$ of terminal ileum resected, and there was no evidence of residual (macroscopic) disease. None of these patients needed nutritional supplements, though four patients had a high daily ileostomy output of $1500-2000 \mathrm{ml} / \mathrm{day}$. All five patients were on antidiarrhoeal medication and took an oral glucoseelectrolyte mixture when the stoma output increased.

\section{Group 2. Short bowel patients maintaining a stable and satisfactory nutritional state without parenteral nutrition. (Table 3)}

The seven patients in this group were nutritionally stable. They were able to maintain their body weight to within $80 \%$ of ideal body weight since the opera- tive procedure which resulted in the short bowel syndrome. Regular anthropometric measurements and biochemical monitoring over three to 60 months showed no change in lean body mass or state of hydration, once oral nutrition or longterm parenteral electrolyte supplementation was established. The median small bowel length in this group was $110 \mathrm{~cm}$ with a range of $60-140 \mathrm{~cm}$.

\section{Group 3. Short bowel patients who failed to maintain} adequate nutritional status without parenteral nutrition. (Table 4)

The five patients in this group had a high daily stoma/ stool output $(2700-4100 \mathrm{ml})$ and rapidly lost weight and became dehydrated without parenteral fluid and electrolyte supplements. These patients restricted their oral intake as food or fluids caused a socially unacceptable increase in stoma/stool output. They lost weight and became malnourished, as judged by anthropometric, clinical and biochemical measures, even if electrolytes were given to prevent dehydration.

Patient no 13 had the transverse and descending colon in situ with a jejunocolic anastomosis at the hepatic flexure, and a colostomy fashioned at the distal end of the descending colon. Patient no 17 had to have most of the small bowel resected because of the development of a volvulus, some years after a colectomy and ileorectal anastomosis for ulcerative colitis. He had a jejunorectal anastomosis and no stoma. The other three patients in this group had end-jejunostomies. Median small bowel length in this group was $50 \mathrm{~cm}$ with a range from 20 to $100 \mathrm{~cm}$. All five patients were established on longterm parenteral nutrition at the time of study.

\section{LABORATORY}

The wet weight of the stoma and stool collections was recorded, and aliquots of $10 \mathrm{ml}$ taken for the estimation of sodium and marker concentrations after homogenisation. Sodium concentrations were measured by flame spectrophotometry (Unicam

Table 2 Ileostomists (controls) (group 1)

\begin{tabular}{|c|c|c|c|c|c|c|c|c|}
\hline \multirow[b]{2}{*}{ No } & \multirow[b]{2}{*}{ Age/sex } & \multirow[b]{2}{*}{ Diagnosis } & \multirow{2}{*}{$\begin{array}{l}\text { Amount of } \\
\text { small bowel } \\
\text { resected }\end{array}$} & \multirow[b]{2}{*}{$\begin{array}{l}\text { Energy } \\
\text { absorption (\%) }\end{array}$} & \multicolumn{4}{|c|}{ Measurements on six hour ileostomy collections } \\
\hline & & & & & $\begin{array}{l}\text { Wet weight } \\
(g)\end{array}$ & $\begin{array}{l}\text { Na output } \\
\text { (mmol) }\end{array}$ & $\begin{array}{l}\text { Dry weight } \\
(g)\end{array}$ & $\begin{array}{l}\text { Energy output* } \\
\text { (kcal) }\end{array}$ \\
\hline 1 & $34 / F$ & CD & Nil & 83 & 478 & 62 & $14 \cdot 0$ & 58 \\
\hline 2 & 40/F & CD & $22 \mathrm{~cm} \mathrm{TI}$ & 91 & 367 & 43 & $11 \cdot 3$ & 29 \\
\hline 3 & 40/M & UC & Nil & 82 & 299 & 38 & $11 \cdot 1$ & 61 \\
\hline 5 & $49 / F$ & CD & $60 \mathrm{~cm} \mathrm{TI}$ & 92 & 132 & 19 & $5 \cdot 9$ & 26 \\
\hline
\end{tabular}

CD: Crohn's disease; UC: ulcerative colitis; TI: terminal ileum; ${ }^{*} 1 \mathrm{kcal}=4 \cdot 2 \mathrm{~kJ}$. 
Table 3 Short bowel patients maintaining a stable and satisfactory nutritional state without parenteral nutrition (group 2)

\begin{tabular}{|c|c|c|c|c|c|c|c|c|c|c|c|c|c|}
\hline \multirow{2}{*}{\multicolumn{2}{|c|}{ No Age/sex }} & \multirow[b]{2}{*}{ Diagnosis } & \multirow[b]{2}{*}{$\begin{array}{l}\text { Residual } \\
\text { small } \\
\text { bowel }\end{array}$} & \multicolumn{2}{|c|}{ Nutritional Support } & \multirow[b]{2}{*}{$\begin{array}{l}\text { Albumin } \\
(\mathrm{g} / \mathrm{l})\end{array}$} & \multirow[b]{2}{*}{$\begin{array}{l}\text { Actual } \\
\text { n weight } \\
\text { (kg) }\end{array}$} & \multirow[b]{2}{*}{$\begin{array}{l}\text { Ideal } \\
\text { weight } \\
\text { (kg) }\end{array}$} & \multirow[b]{2}{*}{$\begin{array}{l}\text { Energy } \\
\text { absorp- } \\
\text { tion (\%) }\end{array}$} & \multicolumn{4}{|c|}{$\begin{array}{l}\text { Measurements on six hour stoma } \\
\text { collections }\end{array}$} \\
\hline & & & & Mode & $\begin{array}{l}\text { Duration } \\
\text { (months) }\end{array}$ & & & & & $\begin{array}{l}\text { Wet } \\
\text { weight } \\
(g)\end{array}$ & $\begin{array}{l}\text { Na output } \\
(\mathrm{mmol})\end{array}$ & $\begin{array}{l}\text { Dry } \\
\text { weight }\end{array}$ & $\begin{array}{c}\text { Energy } \\
\text { output* } \\
\text { g)(kcal) }\end{array}$ \\
\hline 6 & $58 / \mathrm{M}$ & $\begin{array}{l}\mathrm{CD} \\
\text { Carcinoma } \\
\text { rectum }\end{array}$ & $\begin{array}{l}60 \mathrm{~cm} \\
\text { Jejunum }\end{array}$ & IVE & 7 & 35 & 72 & 70 & 59 & 612 & 75 & $26 \cdot 8$ & 130 \\
\hline 7 & $55 / \mathrm{F}$ & $\begin{array}{l}\text { Radiation } \\
\text { enteritis }\end{array}$ & $\begin{array}{l}95 \mathrm{~cm} \\
\text { Jejunum }\end{array}$ & NGE & 60 & 44 & 50 & 57 & 67 & 487 & 57 & $24 \cdot 4$ & 114 \\
\hline 8 & $47 / F$ & $\begin{array}{l}\text { Radiation } \\
\text { enteritis }\end{array}$ & $\begin{array}{l}120 \mathrm{~cm} \\
\text { Jejunum }\end{array}$ & IVE & 36 & 41 & 49 & 61 & 65 & 432 & 47 & $25 \cdot 9$ & 121 \\
\hline 9 & $43 / \mathrm{M}$ & $\mathrm{CD}$ & $\begin{array}{l}115 \mathrm{~cm} \\
\text { Jejunum }\end{array}$ & Sip feeds & 12 & 38 & 54 & 61 & 78 & 260 & 31 & $18 \cdot 3$ & 73 \\
\hline 10 & $30 / \mathrm{F}$ & UC & $\begin{array}{l}140 \mathrm{~cm} \\
\text { Jejunum }\end{array}$ & NG feeds & 7 & 38 & 40 & 48 & 63 & 613 & 80 & $28 \cdot 2$ & 123 \\
\hline 11 & $28 / F$ & UC & $\begin{array}{l}110 \mathrm{~cm} \\
\text { Jejunum }\end{array}$ & NG feeds & 52 & 49 & 53 & 58 & 78 & 427 & 53 & $19 \cdot 6$ & 75 \\
\hline 12 & $54 / \mathrm{F}$ & $\mathrm{CD}$ & $\begin{array}{l}95 \mathrm{~cm} \\
\text { Jejunum }\end{array}$ & IVE & 3 & 39 & 47 & 50 & 77 & 402 & 50 & $18 \cdot 3$ & 80 \\
\hline
\end{tabular}

All patients have had a proctocolectomy. Duration: length of time during which nutritional stability maintained. CD: Crohn's disease. UC: ulcerative colitis. IVE: longterm intravenous electrolytes. NGE: nasogastric electrolytes. ${ }^{*} 1 \mathrm{kcal}=4 \cdot 2 \mathrm{~kJ}$.

SP 90A) and total sodium output over the six hour period calculated.

[3H]-PEG concentrations were determined by liquid scintillation spectroscopy. Each aliquot was pipetted in triplicate into paper cones, dried overnight, and then combusted completely in an oxidiser (Packard Tri-Carb Oxidiser, Packard Instrument $\mathrm{Co}$, Downers Grove, Ill). The oxidiser converts the $[3 \mathrm{H}]$ to tritiated water to which $15 \mathrm{ml}$ of scintillation cocktail (Monophase 40 Plus, Packard Instrument Co) is then added. Samples were counted in a scintillation counter (Packard Tricarb 300C) and mean radioactivity (cpm) was expressed as a percentage of the measured total radioactivity in the test meal. A cumulative marker recovery curve was thus obtained for each patient (Fig. 1), and the time taken to recover $50 \%$ of the meal marker was arbitrarily chosen as a measure of intestinal transit rate. In the single patient without a stoma the marker was only used to measure the completeness of recovery of the meal from the stool collection.

Specimens remaining after taking the above

Table 4 Short bowel patients who failed to maintain adequate nutritional status without parenteral feeding (group 3)

\begin{tabular}{|c|c|c|c|c|c|c|c|c|c|c|c|c|c|}
\hline \multirow[b]{2}{*}{ No } & \multirow[b]{2}{*}{ Age/sex } & \multirow[b]{2}{*}{ Diagnosis } & \multirow[b]{2}{*}{$\begin{array}{l}\text { Residual } \\
\text { small } \\
\text { bowel }\end{array}$} & \multirow[b]{2}{*}{$\begin{array}{l}\text { Bowel } \\
\text { large } \\
\text { bowel }\end{array}$} & \multirow[b]{2}{*}{$\begin{array}{l}\text { Albumin } \\
(g / l)\end{array}$} & \multirow[b]{2}{*}{$\begin{array}{l}\text { Actual } \\
\text { weight } \\
(k g)\end{array}$} & \multirow[b]{2}{*}{$\begin{array}{l}\text { Ideal } \\
\text { weight } \\
(\mathrm{kg})\end{array}$} & \multirow{2}{*}{$\begin{array}{l}\text { Mean } \\
\text { daily } \\
\text { stomal } \\
\text { stool } \\
\text { output } \\
\text { (ml) }\end{array}$} & \multirow[b]{2}{*}{$\begin{array}{l}\text { Energy } \\
\text { absorp- } \\
\text { tion (\%) }\end{array}$} & \multicolumn{4}{|c|}{$\begin{array}{l}\text { Measurements on six hour stomal } \\
\text { stool collections }\end{array}$} \\
\hline & & & & & & & & & & $\begin{array}{l}\text { Wet } \\
\text { weight } \\
(g)\end{array}$ & $\begin{array}{l}\text { Na output } \\
\text { ( } \mathrm{mmol})\end{array}$ & $\begin{array}{l}\text { Dry } \\
\text { weight }(g\end{array}$ & $\begin{array}{c}\text { Energy } \\
\text { output } \ddagger \\
\text { g)(kcal) }\end{array}$ \\
\hline 13 & $57 / F$ & $\begin{array}{r}\text { Radiation } \\
\text { enteritis }\end{array}$ & $\begin{array}{l}30 \mathrm{~cm} \\
\text { Jejunum }\end{array}$ & $50 \% *$ & 39 & 62 & 58 & 2700 & 27 & 567 & 61 & $48 \cdot 9$ & 248 \\
\hline 14 & $32 / \mathrm{F}$ & $\begin{array}{l}\text { Desmoid } \\
\text { tumour. } \\
\text { Polyposis }\end{array}$ & $\begin{array}{l}60 \mathrm{~cm} \\
\text { Jejunum }\end{array}$ & Nil & 45 & 44 & 51 & 3200 & 63 & 292 & 29 & $29 \cdot 2$ & 134 \\
\hline 15 & $50 / F$ & $\mathrm{CD}$ & $\begin{array}{l}100 \mathrm{~cm} \\
\text { Jejunum }\end{array}$ & Nil & 36 & 60 & 59 & 4100 & 33 & 744 & 87 & $50 \cdot 1$ & 224 \\
\hline 16 & $17 / \mathrm{M}$ & Volvulus & $\begin{array}{l}20 \mathrm{~cm} \\
\text { Jejunum }\end{array}$ & $\dagger$ & 42 & 47 & 63 & 3500 & 2 & 799 & 77 & $71 \cdot 9$ & 328 \\
\hline 17 & $29 / \mathrm{M}$ & $\begin{array}{l}\text { UC } \\
\text { Volvulus }\end{array}$ & $\begin{array}{l}50 \mathrm{~cm} \\
\text { Jejunum }\end{array}$ & Rectum & 35 & 58 & 64 & 4000 & 3 & 1500 & 144 & $72 \cdot 8$ & 330 \\
\hline
\end{tabular}

CD: Crohn's disease; UC: ulcerative colitis; *See text; †Defunctioned colon in situ. Mean daily stoma/stool outputs were determined when patients were taking oral food and fluids. $¥ 1 \mathrm{kcal}=4 \cdot 2 \mathrm{~kJ}$. 


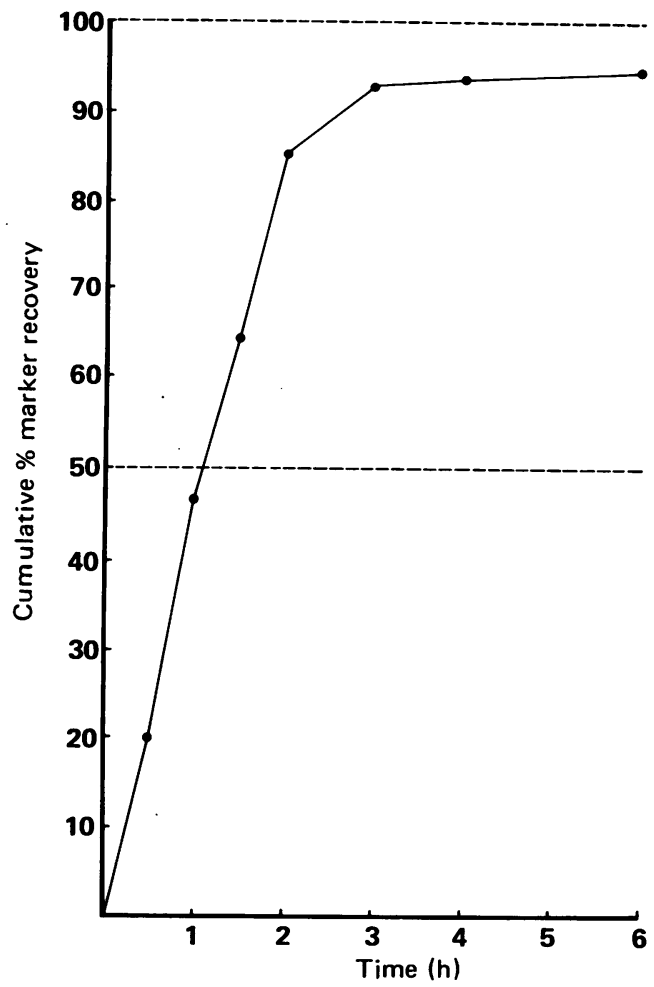

Fig. 1 Cumulative \% meal marker ([3H]-PEG) recovery curve over a six hour study period, from the stoma of a patient (no 8) with the short bowel syndrome, after taking $300 \mathrm{ml}$ Ensure orally.

aliquots were immediately frozen to $-20^{\circ} \mathrm{C}$ and freeze dried (Chemlab SB3 freeze-dryer) until a constant weight was obtained. The dry weights of the six hour stoma/stool collections were calculated by correcting for the removal of these aliquots. The energy losses in the collections and the energy content of the test meals were measured by bomb calorimetry of the dried samples. ${ }^{10}$

STATISTICAL ANALYSIS

The statistical significance of the results was determined by using the Mann-Whitney U Test.

\section{Results}

MAR KER RECOVERIES (Table 5, Figures 1, 2)

Figure 1 shows a typical cumulative marker recovery curve obtained in a single patient from group 2 , and in Figure 2 the three curves are presented as the median at different times for all patients in each group. Median total marker recoveries in the six hour test period were virtually complete (Table 5), but the time taken to recover $50 \%$ of the marker from the
Table 5 Marker recoveries in the three patient groups*

\begin{tabular}{lll}
\hline & $\begin{array}{l}\text { Total marker } \\
\text { recovery } \\
(\%)\end{array}$ & $\begin{array}{l}\text { Time to 50\% } \\
\text { marker } \\
\text { recovery (min) }\end{array}$ \\
\hline Group & 97 & 186 \\
1 Ileostomists & $(91-109)$ & $(156-222)$ \\
$(\mathrm{n}=5)$ & 99 & $83 \dagger$ \\
2 Short bowel & $(95-104)$ & $(53-165)$ \\
No IVN $(\mathrm{n}=7)$ & 98 & $53 \dagger$ \\
3 Short bowel & $(90-106)$ & $(29-72) \dagger$ \\
IVN $(\mathrm{n}=5)$ & & \\
\hline
\end{tabular}

*Median and range; $†$ Difference from ileostomists significant at $5 \%$ level (Mann-Whitney U Test).

stoma was less in both short bowel groups compared with the ileostomists (difference significant at $5 \%$ level with both groups). There was no significant difference in the $50 \%$ marker recovery times between the two short bowel groups, though there

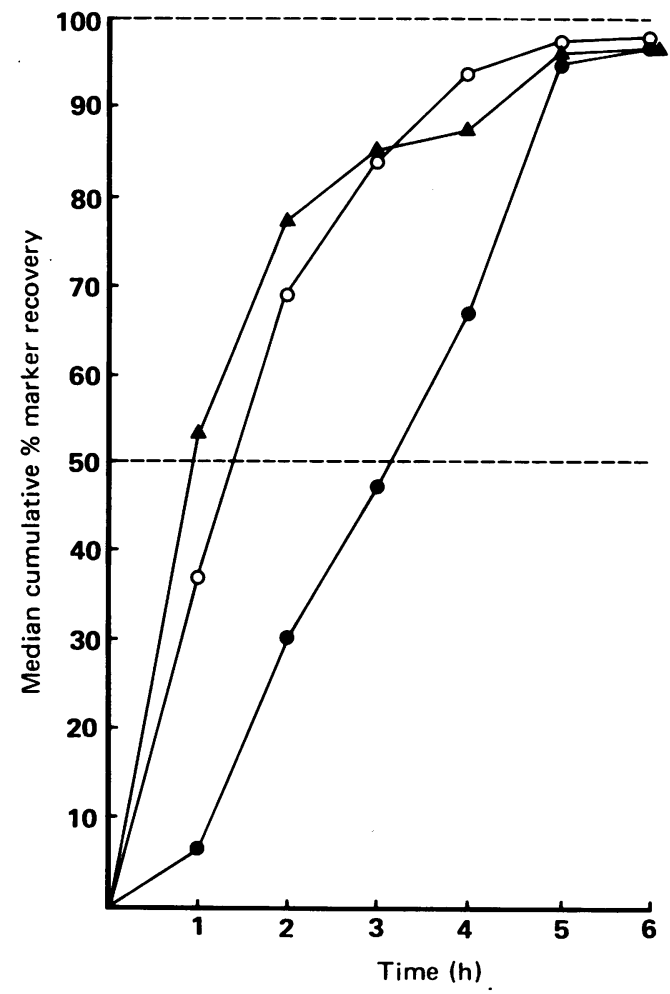

Fig. 2 Calculated median cumulative \% meal marker ([3H]-PEG) stoma recoveries over a six hour study period in three patient groups after taking $300 \mathrm{ml}$ Ensure orally.

Group 1: ileostomists, $\bigcirc$ group 2: short bowel patients, * $\Delta$ group 3: short bowel patients on longterm parenteral nutrition. * *Time to $50 \%$ marker recovery: difference from group 1 significant at $5 \%$ level (Mann-Whitney U Test). 
Table 6 Six hour fasting outputs in the three patients groups

\begin{tabular}{lllll}
\hline & $\begin{array}{l}\text { Patient } \\
\text { number }\end{array}$ & $\begin{array}{l}\text { Energy } \\
\text { output } \\
(\text { (kcal) }\end{array}$ & $\begin{array}{l}\text { Wet } \\
\text { weight } \\
(\mathrm{g})\end{array}$ & $\begin{array}{l}\text { Dry } \\
\text { weight } \\
(\mathrm{g})\end{array}$ \\
\hline Group 1 & & & & \\
Ileostomists & 1 & 18 & 177 & $4 \cdot 0$ \\
& 4 & 26 & 277 & $5 \cdot 5$ \\
Group 2 & & & & \\
Short bowel no IVN & 7 & 23 & 191 & $4 \cdot 8$ \\
& 8 & 12 & 59 & 1.8 \\
& 9 & 10 & 34 & $1 \cdot 8$ \\
Group 3 & & & & \\
Short bowel IVN & 15 & 27 & 109 & $6 \cdot 1$ \\
& 16 & 42 & 150 & 8.2 \\
& 17 & 26 & 290 & 6.7 \\
\hline
\end{tabular}

$* 1 \mathrm{kcal}=4 \cdot 2 \mathrm{~kJ}$.

was a trend to faster intestinal transit in the patients who needed parenteral nutrition.

FASTING VALUES (Table 6)

The energy content of the six hour fasting collections was low: 10-42 kcal (42-176 kJ). Nevertheless, this indicates that endogenous secretions can lead to an underestimation of the proportion of energy absorbed from a test meal, in this study up to $12 \%$ when a test meal containing $337 \mathrm{kcal}(1415 \mathrm{~kJ})$ was given.

ENERGY A BSORPTION (Tables 2-4, 7-8, Figures 3-4)

In two patients in whom the tests were done twice, the percentage absorption of energy was similar on

Table 7 Energy balance repeatability studies

A: Patients studied twice:

\begin{tabular}{lll}
\hline \multirow{2}{*}{ No } & \multicolumn{2}{c}{ Energy absorption } \\
\cline { 2 - 3 } & 1 & 2 \\
\hline 12 & $76 \%$ & $79 \%$ \\
17 & $3 \%$ & $3 \%$
\end{tabular}

B: Energy absorption compared with results obtained from a previous study:*

\begin{tabular}{rll}
\hline No & Present study & Previous study \\
\hline 7 & $67 \%$ & $67 \%$ \\
11 & $78 \%$ & $66 \%$ \\
15 & $33 \%$ & $36 \%$ \\
\hline
\end{tabular}

*Reference no 14: energy balance carried out by analysing a 24 hour stoma collection, while patients took only Ensure by mouth.
Table 8 Results for the patients in the three clinical groups (median and range)

\begin{tabular}{|c|c|c|c|c|}
\hline Group & $\begin{array}{l}\% \text { Energy } \\
\text { absorption }\end{array}$ & $\begin{array}{l}\text { Dry wt } \\
(g)\end{array}$ & $\begin{array}{l}\text { Wet wt } \\
(\mathrm{g})\end{array}$ & $\begin{array}{l}\text { Sodium } \\
\text { output } \\
\text { (mmol) }\end{array}$ \\
\hline  & $\begin{array}{l}87 \\
(82-92)\end{array}$ & $\begin{array}{l}11 \\
(6-14)\end{array}$ & $\begin{array}{l}299 \\
(132-478)\end{array}$ & $\begin{array}{l}38 \\
(19-62)\end{array}$ \\
\hline $\begin{array}{l}2 \text { Short bowel } \\
\text { No IVN }(n=7)\end{array}$ & $\begin{array}{l}67 \\
(59-78)\end{array}$ & $\begin{array}{l}24 \\
(18-28)\end{array}$ & $\begin{array}{l}432 \\
(260-613)\end{array}$ & $\begin{array}{l}53 \\
(31-80)\end{array}$ \\
\hline $\begin{array}{l}3 \text { Short bowel } \\
\text { IVN }(n=5)\end{array}$ & $\begin{array}{l}27 \\
(2-63)\end{array}$ & $\begin{array}{l}50 \\
(29-73)\end{array}$ & $\begin{array}{l}744 \\
(292-1500)\end{array}$ & $\begin{array}{l}77 \\
(29-144)\end{array}$ \\
\hline $\begin{array}{l}\text { Differences * } \\
\text { between groups } \\
\text { significant at: }\end{array}$ & $\begin{array}{l}1 \% \\
\text { Level }\end{array}$ & $\begin{array}{l}1 \% \\
\text { Level }\end{array}$ & NS & NS \\
\hline
\end{tabular}

*Mann-Whitney U Test; NS: not significant.

both occasions. In three patients per cent energy absorption from this single test meal agreed well with values obtained in a previous study 14 using a 24 hour balance period during which only Ensure was taken instead of food (Table 7).

Median percentage energy absorption was greatest in the ileostomists $(87 \%)$, less in short bowel patients in group $2(67 \%)$, and smallest in the short bowel patients in group 3 who needed parenteral nutrition (27\%) (Fig. 3). The differences between the three groups were all significant at the $1 \%$ level. All the ileostomists absorbed more than $80 \%$ of the energy content of the test meal, the intermediate short bowel group absorbed between $59 \%$ and $78 \%$ of energy, and four of five patients in group 3 absorbed less than $35 \%$ of energy. The dry weight of the six hour stoma/ stool collection correlated well with energy absorption $(r=-0.99, p<0.001$, Fig. 4a) and the median dry weights of the three patient groups were also significantly different from each other (Table 4). Energy absorption correlated with transit rate (time to $50 \%$ marker recovery: $r=0.73, p<0.01$, Fig. $4 b$ ), and residual jejunal length measured at operation from the ligament of Treitz $(r=0 \cdot 73, p<0.01$, Fig. $4 c)$.

SODIUM AND WATER (Tables 2-4, 8, Figure 4d) Although median wet weight of the stoma/stool collections was least in the ileostomists, greater in group 2 and greatest in group 3 , these differences were not significant probably because of interpatient variation within each group. The median sodium outputs in the three patient groups followed a similar trend, and again the differences between groups were not significant. As expected there was a close correlation between sodium output and wet weight $(r=0.98$, $\mathrm{p}<0.001$ ). Energy absorption correlated with wet weight, though not as well as with the dry weight $(r=-0.83, p<0 \cdot 001$, Fig. 4d). 




Fig. 3 Energy absorption (\%) from $300 \mathrm{ml}$ Ensure in three patient groups. Group 1: ileostomists, group 2: short bowel patients, group 3: short bowel patients on longterm parenteral nutrition. Horizontal bars represent median values. Differences between groups significant at the $1 \%$ level (Mann-Whitney U Test).

\section{Discussion}

In this study, total energy absorption from a liquid test meal containing a balanced mixture of nutrients was chosen as the parameter used to measure the severity of intestinal failure. Malabsorption of all the major individual nutrients has been well documented in patients with a short gut. ${ }^{11-16}$ Our aim was to develop a simple measure of intestinal absorption relevant to clinical practice and for this purpose it seemed appropriate to use a measure of total energy absorption.

We did not use a solid meal as this would probably have prolonged the duration of the test. A recent study has shown, however, that the absorption of nutrients in short bowel patients is similar whether solid meals or a liquid diet is taken. ${ }^{14}$ All patients tolerated the study well, and even in those patients with large daily losses from the bowel, the study period was not long enough to be complicated by major fluid and/or electrolyte imbalance.

The recovery of non-absorbable marker from the stoma or stool collections was virtually complete in the six hour study period. As expected short bowel patients had a more rapid mouth-to-stoma transit rate than ileostomists, with a trend to faster transit in the most severely affected group. This confirms previous observations ${ }^{11}$ of rapid intestinal transit rate in short bowel patients.

For the clinician it is important to know if a patient is likely to need longterm parenteral nutrition. This energy balance test seems to be able to differentiate between ileostomists who do not need any special nutritional treatment, short bowel patients in need of parenteral nutrition, and an intermediate group of short bowel patients who need less intensive nutritional support. With one exception the short bowel patients in need of parenteral nutrition absorbed less than $35 \%$ of test meal energy. In all such balance studies the endogenous intestinal secretions may lead to underestimation of the proportion of energy absorbed, and fasting studies do provide some indication of the magnitude of this error. For clinical practice, however, a single study of absorption from the test meal without correction for fasting energy loss seems to give useful results.

Energy absorption was also found to correlate with residual jejunal length, transit time, and wet weight of the stoma/stool output. These correlations may have physiological significance, but they are unlikely to be useful in the management of individual patients. For example, three patients with jejunal lengths of $95-100 \mathrm{~cm}$ had widely varying energy absorptions (Fig. 4c). In Figure 4b, there are five patients with energy absorptions of between $75 \%$ and $85 \%$ whose transit rates vary from 90 to $222 \mathrm{~min}$. In Figure 4d, two patients in group 3 with similar low energy absorptions of $2 \%$ and $3 \%$ had corresponding wet weights of 799 and $1500 \mathrm{~g}$ respectively.

An interesting close correlation between energy absorption and dry weight of the effluent was observed. It is possible that an even simpler measure of absorption, a comparison between the dry weight of a feed composed of totally absorbable nutrients and the dry weight of the effluent, may give as good results as the energy balance reported here. This possibility will be the subject of further study.

Previous studies in normal subjects ${ }^{17-20}$ have shown that the absorption of protein, carbohydrate and fat from liquid meals begins in the duodenum and is largely completed in the first $100 \mathrm{~cm}$ of jejunum. One study ${ }^{20}$ found that $90 \%$ of the carbohydrate in three different test meals was absorbed in the first $30 \mathrm{~cm}$ of jejunum. Accelerated intestinal transit may be at least partly responsible for impaired absorption in 

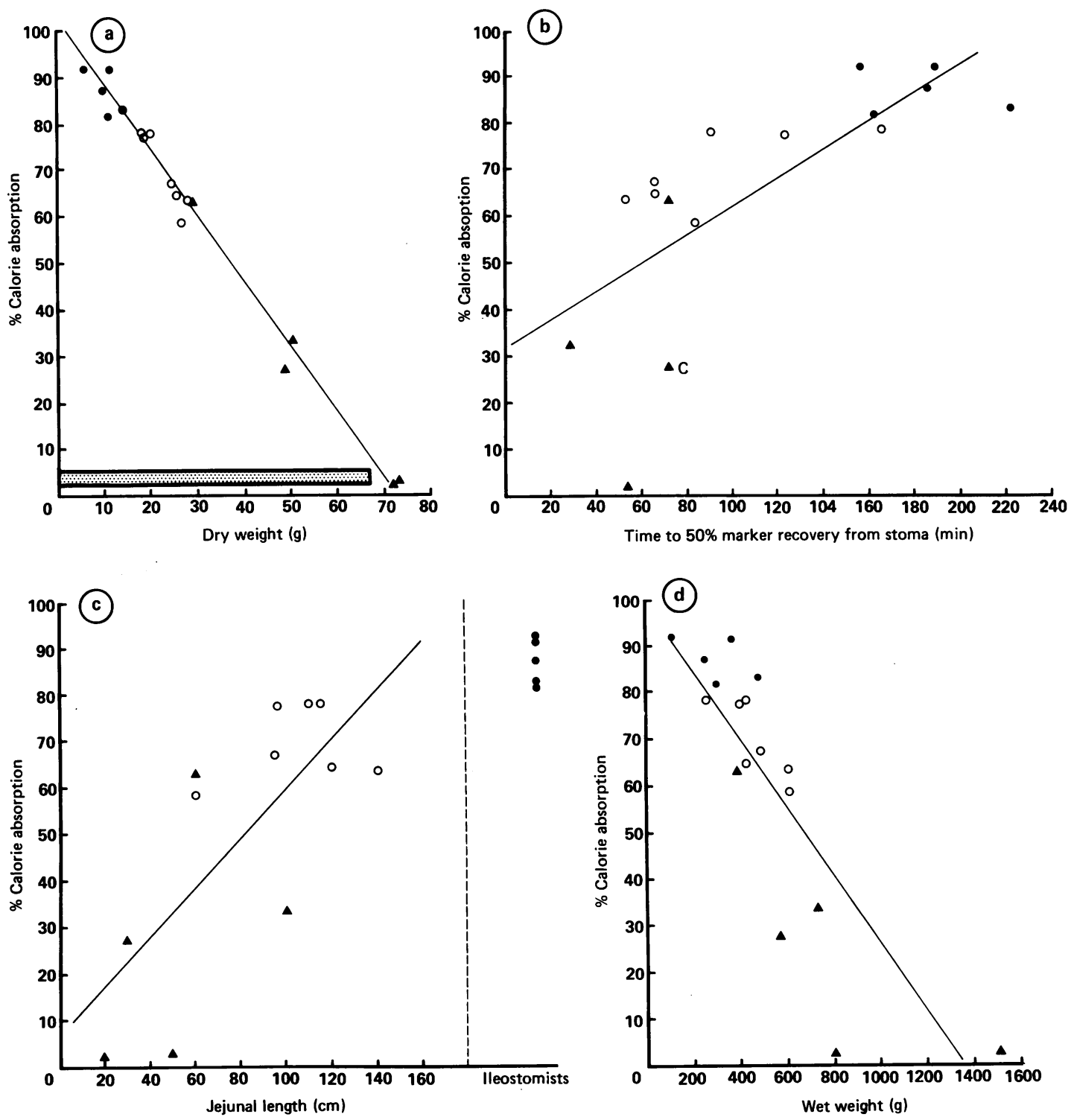

Fig. 4 Correlations between \% energy absorption from $300 \mathrm{ml}$ Ensure and the following four parameters in the three patient groups studied. Group 1: ileostomists, $\bigcirc$ group 2: short bowel patients, $\Delta$ group 3: short bowel patients on longterm parenteral nutrition. (a) Dry weight of the stoma/stool output over the six hour study period in 17 patients. $r=-0.99$, $p<0.001$. Dry weight of $300 \mathrm{ml}$ Ensure $=67.3 \mathrm{~g}$. (b) Transit rate (time taken to recover $50 \%$ of the meal marker, $[3 H]-P E G$, from the stoma) in 16 patients. $r=0.73, p<0.01$, C: Patient with colostomy. (c) Residual jejunal length (cm) in 12 short bowel patients. $r=0.73, p<0.01$. Group 1 patients are plotted separately because the residual small bowel length is unknown. (d) Wet weight of the six hour stoma/stool collections. $r=-0.83, p<0.001$.

patients with a short gut. Studies in normal subjects ${ }^{21}$ and ileostomists ${ }^{22}$ have shown that drugs which increase transit rate can decrease nutrient absorption. Removal of the ileal brake ${ }^{2324}$ may be important in patients with no ileum and a reduced length of jejunum. In our study the short bowel patients had a more rapid intestinal transit rate and reduced energy absorption compared with the ileostomists. We did not study the influence of the rate of gastric emptying on intestinal transit, but another study ${ }^{25}$ has failed to 
show any difference in gastric emptying rate and postprandial motor activity between normal controls and patients with a short gut.

This simple non-invasive test of energy absorption may be useful in helping to identify those patients who need parenteral nutrition. It may also be repeated to follow the course of intestinal adaptation and thus predict when parenteral nutrition can be reduced or stopped. In addition, it could be used to study the effect of different diets or drugs on intestinal absorption in patients with the short bowel syndrome.

Presented at the Annual Meeting of the American Gastroenterological Association, Chicago, May 1987 and published as an abstract. The authors thank Dr P B McIntyre for permission to use some of his data for comparison purposes and Mrs M Fitchew for laboratory assistance. C A Rodrigues received a grant from the North East Thames Regional Health Authority.

\section{References}

1 Jeejeebhoy KN. Therapy of the short-gut syndrome. Lancet 1983; i: 1427-30.

2 Krejs GJ. The small bowel, Part 1: Intestinal resection. Clin Gastroenterol 1979; 8: 373-86.

3 Weser $E$. The management of patients after small bowel resection. Gastroenterology 1976; 71: 146-50.

4 Hill GL. Massive Enterectomy: indications and management. World J Surg 1985; 9: 833-41.

5 Gouttebel C, Saint-Aubert B, Astre C, Joyeux H. Total parenteral nutrition needs in different types of short bowel syndrome. Dig Dis Sci 1986; 7: 718-23.

6 Harrison RJ, Booth CC. Massive resection of the small intestine after occlusion of the superior mesenteric artery. Gut 1960; 1: 237-41.

7 Anderson CM. Long-term survival with six inches of small intestine. Br Med J 1965; i: 419-22.

8 Winawer SJ, Broitman SA, Wolochow DA, Osborne MP, Zamchek N. Successful management of massive small-bowel resection based on an assessment of absorption defects and nutrient needs. $N$ Engl J Med 1966; 274: 72-8.

9 Walker-Smith J, Wyndham N. Total loss of mid-gut. Med J Aust 1967; i: 857-60.
10 Miller DS, Payne PR. A ballistic bomb calorimeter. Br J Nutr 1959; 13: 501-8.

11 Booth CC. The metabolic effects of intestinal resection in man. Postgrad Med J 1961; 37: 725-39.

12 Hylander E, Ladefoged K, Jarnum S. Nitrogen absorption following small-intestinal resection. Scand J Gastroenterol 1980; 15: 853-8.

13 Woolf GM, Miller C, Kurian R, Jeejeebhoy KN. Diet for patients with a short bowel: High fat or high carbohydrate? Gastroenterology 1983; 84: 823-8.

14 McIntyre PB, Fitchew M, Lennard-Jones JE. Patients with a high jejunostomy do not need a special diet. Gastroenterology 1986; 91: 25-33.

15 Woolf GM, Miller C, Kurian R, Jeejeebhoy KN. Nutritional absorption in short bowel syndrome. Evaluation of fluid, calorie, and divalent cation requirements. Dig Dis Sci 1987; 32: 8-15.

16 Ameen VZ, Powell GK, Annette Jones L. Quantitation of fecal carbohydrate excretion in patients with short bowel syndrome. Gastroenterology 1987; 92: 493-500.

17 Borgstrom B, Dahlqvist A, Lundh G, Sjovall J. Studies of intestinal digestion and absorption in the human. J Clin Invest 1957; 36: 1521-36.

18 Johansson C. Studies of gastrointestinal interactions. V11. Characteristics of the absorptive pattern of sugar, fat, and protein from composite meals in man. A quantitative study. Scand J Gastroenterol 1975; 10: 3342.

19 Nixon SE, Mawer GE. The digestion and absorption of protein in man. 1. The site of absorption. BrJ Nutr 1970; 24: $227-40$

20 Ruppin H, Bar-Meir S, Soergel KH, Wood CM. Effects of liquid formula diets on proximal gastrointestinal function. Dig Dis Sci 1981; 26: 202-7.

21 Holgate AM, Read NW. Metoclopramide reduces carbohydrate absorption in man. Br J Clin Pharmacol 1985; 19: 67-72.

22 Holgate AM, Read NW. Relationship between small bowel transit time and absorption of a solid meal. Influence of metoclopramide, magnesium sulphate and lactulose. Dig Dis Sci 1983; 28: 812-9.

23 Spiller RC, Trotman OF, Higgins BE, et al. The ileal brake - inhibition of jejunal motility after ileal fat perfusion in man. Gut 1984; 25: 365-74.

24 Holgate AM, Read NW. Effect of ileal infusion of Intralipid on gastrointestinal transit, ileal flow rate, and carbohydrate absorption in humans after ingestion of a liquid meal. Gastroenterology 1985; 88: 1005-11.

25 Remington M, Malagelada J-R, Zinsmeister A, Fleming CR. Abnormalities in gastrointestinal motor activity in patients with short bowels: effect of a synthetic opiate. Gastroenterology 1983; 85: 629-36. 